\title{
High Erythroid Burst-promoting Activity in Sera from Umbilical Cord Blood
}

\author{
Takashi Terasawa, ${ }^{*} * * *$ Toshiharu Ito, ${ }^{*}$ Minoru MatSudA,* \\ Tatsuro Azuma, ** and Shiro KasaI* \\ * Department of Physiology, Tohoku Dental University, Koriyama, \\ Fukushima, 963 Japan \\ ** Department of Obstetrics and Gynecology, Jusendo General Hospital, \\ Koriyama, Fukushima, 963 Japan
}

\begin{abstract}
Using methylcellulose clonal cell cultures, we examined human erythroid burst-promoting activity (BPA) in sera obtained from umbilical cord blood. BPA was measured on the basis of the number of erythroid bursts (BFU-E) and hemoglobin synthesis when peripheral blood mononuclear cells were cultured with cord blood serum in the presence of 1.0 $\mathrm{U} / \mathrm{ml}$ erythropoietin (Epo) at low fetal calf serum concentration $(10 \%)$. Controls were cultured with adult serum. The number of BFU-E and hemoglobin synthesis increased in culture to which cord blood serum had been added, and the enhancing effects of cord blood serum on erythroid burst formation were more pronounced than in control cultures with $2.0 \mathrm{U} / \mathrm{ml}$ Epo. No erythroid bursts, however, grew in the cultures with cord blood serum in the absence of Epo. Increased sensitivity of erythroid burst formation to low concentrations of Epo was observed in cultures containing cord blood serum. Dose-relationships between the concentrations of cord blood serum and the number of BFU-E and hemoglobin synthesis were clearly observed. We therefore concluded that the stimulatory effects of cord blood serum on erythroid burst formation may be due to BPA, one of the factors required for the proliferation of erythroid precursors at an early stage.
\end{abstract}

Key Words: BFU-E, BPA.

The clonal erythropoietic cell culture method has made it possible to detect two classes of erythroid progenitor cells: early-stage erythroid progenitors (less differentiated), designated as burst-forming unit erythroids (BFU-E) or erythroid bursts, and late-stage erythroid progenitors (highly differentiated), designated as colony-forming unit erythroids (CFU-E) (EAVES et al., 1979). These progenitor

Received for publication July 6, 1983

*** To whom reprint requests should be addressed.

寺沢 崇, 伊藤俊晴, 松田 棇, 吾妻垟郎, 葛西四朗 
cells are distinguishable on the basis of their proliferation capabilities (OGAwA et al., 1977), erythropoietin requirements, incubation periods (AXELRAD et al., 1974), and fetal hemoglobin augmentation capabilities (KIDOGUCHI et al., 1978). Generally, CFU-E are found only in bone marrow and BFU-E in both bone marrow and peripheral blood in the normal state.

Both CFU-E and BFU-E need the glycoprotein hormone, erythropoietin (Epo), for their colony formation in virto. Similarly, CFU-E in vivo requires Epo for growth and proliferation. However, the number of BFU-E in vivo does not correlate with endogenous Epo levels (LAJTHA et al., 1971; HARA and OGAWA, 1978; ISCOVE and GUILBERT, 1978), so it appears that humoral substances other than Epo may regulate the early stages of erythropoiesis. It has been reported that the addition of certain types of cell and/or cellular products referred to as burst-promoting activity (BPA) enhances the growth of BFU-E in vitro. The conditioned medium of human peripheral blood leukocytes (AYE, 1977) or bone marrow cells (PoRTER and OGawa, 1982), T-lymphocytes (NATHAN et al., 1978), and macrophages (KURLAND et al., 1980) increased the number of bursts observed in cultures of bone marrow or peripheral blood. In addition, we reported that extracts from the irradiated spleen cells of rats contained BPA-like activity (KASAI et al., 1980). Subsequently, the presence of high levels of BPA was found in sera of patients with aplastic anemia (Nissen et al., 1979; KigaSAwa and Nishinira, 1980). Since fetal erythropoiesis is extremely active in spite of low Epo levels (HALVORSEN, 1963), we examined the effect of cord blood serum on erythroid burst formation. It was observed that cord blood serum promotes the growth of BFU-E in culture.

\section{MATERIALS AND METHODS}

Serum samples. Cord blood serum samples $(5 \mathrm{ml})$ were drawn from umbilical cords of normal pregnant women at 38-42-week gestation. Adult serum samples $(5 \mathrm{ml})$ were obtained by venipuncture from healthy volunteers.

Erythropoietic cell culture. Blood samples for culture were obtained from healthy volunteers of " $O$ " blood group and the mononuclear cells were separated by the Ficoll-Isopaque method (Pharmacia Fine Chemical Corp., Sweden). Erythropoietic cell culture was performed for 14 days using a modification (OGAwA et al., 1977) of the methylcellulose clonal assay developed by IsCove et al. (1974). Briefly, $3 \times 10^{5}$ blood mononuclear cells were plated in culture dishes in a $1 \mathrm{ml}$ mixture containing $\alpha$-medium (Flow Labs. Inc., Rockville, Md.), 0.8\% methylcellulose (Fisher Scientific Co., Norcross, Ga.), $1 \%$ deionized bovine serum albumin (Sigma Scientific Co., St. Louis, Mo.), 10\% fetal calf serum (Sterile System Inc., Logan, Ut.), and $1.0 \mathrm{U} / \mathrm{ml}$ of sheep-plasma erythropoietin (Connaught Lab. Ltd., Willowdale, Ontario, Canada, specific activity $15 \mathrm{U} / \mathrm{mg}$ protein) unless other specified. Adult or cord-blood serum was added at a concentration of $10 \%$ unless otherwise specified. Cultures were incubated in a humidified atmosphere flushed 
with air containing $5 \% \mathrm{CO}_{2}$. Erythroid bursts were scored at day 14 under an inverted microscope.

Hemoglobin synthesis. On day 13 of incubation, cultures were labelled with $0.2 \mathrm{ml}$ of $\alpha$-medium containing $50 \%$ fetal calf serum and $0.5 \mu \mathrm{Ci}$ of ${ }^{59} \mathrm{FeCl}_{3}(\mathrm{NZE}-$ 037, New England Nuclear Corp., Boston, Ma.). After $24 \mathrm{hr}$ of labelling, heme was extracted using acid-methylethylketone and the activity was measured with a gas flow counter (TEALE, 1959).

\section{RESULTS}

It is well known that erythroid burst-forming efficiency is dependent not only on the Epo concentration but also on the fetal calf serum concentration of a culture. TERASAwA et al. (1980) reported that fetal calf serum contained some BPA. Therefore, a culture system using a low concentration of fetal calf serum $(10 \%)$ was employed to detect the BPA in cord blood serum without the influence of the BPA existing in fetal calf serum. When examining the effect of cord blood serum on BFU-E growth, we observed that it increased the number of BFU-E and the size of the colonies determined by hemoglobin synthesis in cultures of human adult peripheral blood mononuclear cells to a greater extent than in control cultures with adult serum (Fig. 1). The magnitude of the response of BFU-E colony formation and hemoglobin synthesis to cord blood serum varied from donor to donor, as did the bursts grown under conditions of low fetal calf serum. The relation between hemoglobin synthesis and plating efficiency was not always parallel because bursts appeared to be larger in the presence of cord blood serum. Furthermore, it is to be noted that cultures with cord blood serum and $1.0 \mathrm{U} / \mathrm{ml}$ of Epo revealed a greater number of BFU-E than control cultures with $2.0 \mathrm{U} / \mathrm{ml}$ of Epo (Fig. 1, Exp. 3 and Exp. 4). However, no erythroid colonies were formed in cultures with only $20 \%$ cord blood serum in the absence of Epo (Fig. 1, Exp. 4).

Figure 2 shows the well-hemoglobinized and large-size erythroid bursts observed in a culture with cord blood serum under the condition of low fetal calf serum concentration.

The effect of varying concentrations of cord blood serum on BFU-E growth in peripheral blood mononuclear cells in the presence of Epo is shown in Fig. 3. The cord blood serum induced dose-related increases in the number of BFU-E and in hemoglobin synthesis at a constant concentration of $1.0 \mathrm{U} / \mathrm{ml}$ of Epo. A maximum stimulation, in which about 2.5 times the number of BFU-E grown in control cultures was observed, was obtained with $10 \%$ cord blood serum. In the case of adult serum, however, no dose-response was observed. No dose-related inhibitory effect was seen under these conditions.

The effect of cord blood serum on peripheral blood BFU-E grown was also investigated at various concentrations of Epo (Fig. 4). It was observed that ery- 

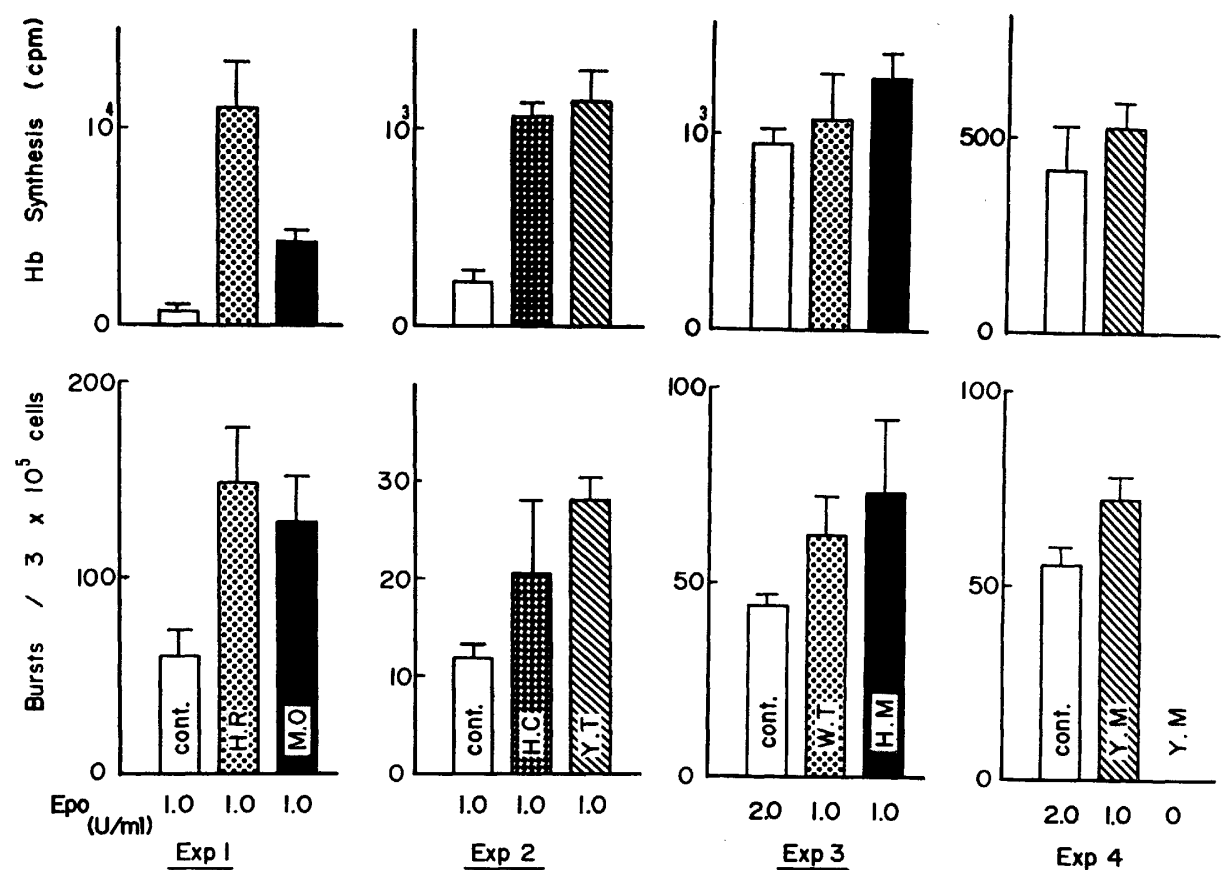

Fig. 1. Effect of cord blood serum on erythroid burst formation (lower) and hemoglobin synthesis (upper). Peripheral blood mononuclear cells $\left(3 \times 10^{5}\right.$ cells $\left./ \mathrm{ml}\right)$ were plated in a $1 \mathrm{ml}$ culture containing Epo, 10\% FCS and $10 \%$ cord blood serum or $10 \%$ adult serum as control cultures (cont.). The initials on the columns represent the names of the pregnant women from whom the cord blood serum samples were collected. In Y.M, Exp. 4 , cells were cultured with $20 \%$ cord blood serum in the absence of Epo. Results are expressed as mean \pm S.D. (3 plates).

throid burst formation and hemoglobin synthesis tended to respond to low levels of Epo in the cultures with cord blood serum, in contrast to the controls.

\section{DISCUSSION}

In the present study, we demonstrated that umbilical cord blood serum enhanced erythroid burst formation in peripheral blood mononuclear cell cultures. It has been reported that the concentrations of Epo in cord blood serum are less than $0.1 \mathrm{U} / \mathrm{ml}$ (HALVORSEN, 1963) and that such low concentrations are insufficient for growth of erythroid bursts in culture. Our present data also demonstrated that no growth of BFU-E colonies were observable when cultures were incubated with cord blood serum without Epo, although we did not measure the concentration of Epo in cord blood serum. It is possible, therefore, that the stimulatory effect of cord blood serum on BFU-E colony formation may be due to BPA rather than Epo. 


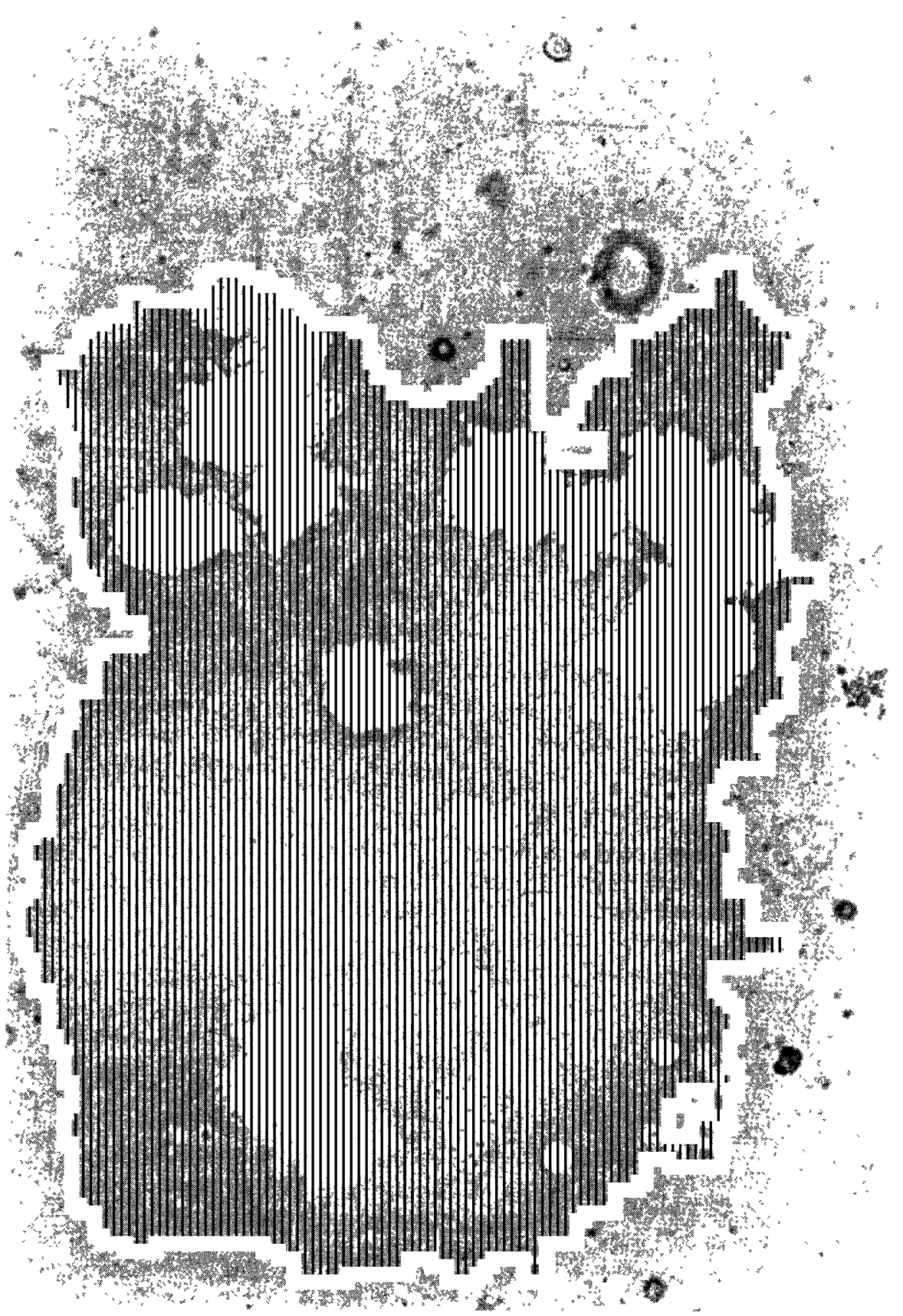

Fig. 2. The well-hemoglobinized and large erythroid bursts (BFU-E) in a culture containing $10 \%$ cord blood serum under the condition of low fetal calf serum $(10 \%)$ observed by inverted microscope, $\times 200$. 


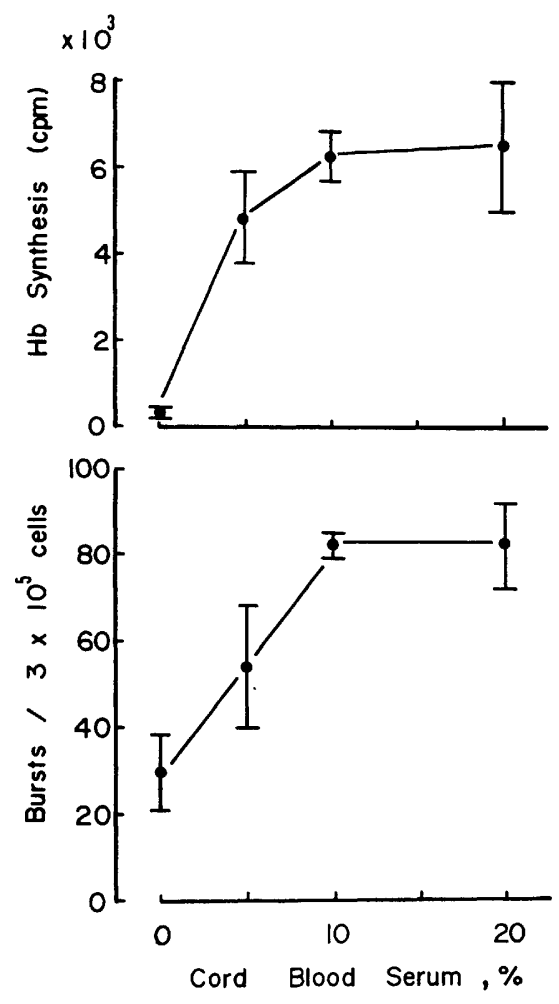

Fig. 3.
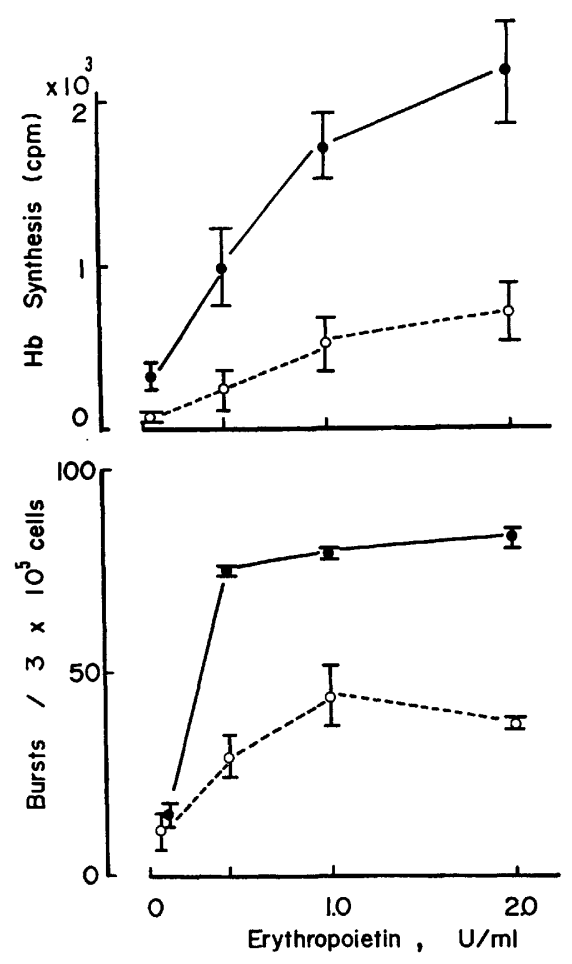

Fig. 4

Fig. 3. Effect of the addition of cord blood serum (case N.K) on erythroid burst formation (lower) and hemoglobin synthesis (upper). Peripheral blood mononuclear cells $\left(3 \times 10^{5}\right.$ cells $/ \mathrm{ml}$ ) were cultured in the presence of increasing concentrations of cord blood serum at constant concentrations of Epo $(1.0 \mathrm{U} / \mathrm{ml})$ and $10 \%$ FCS. Results are expressed as mean \pm S.D. (3 plates).

Fig. 4. Growth of erythroid bursts (lower) and hemoglobin synthesis (upper) from $3 \times 10^{5}$ peripheral blood mononuclear cells at varying concentrations of Epo in the presence of $10 \%$ cord blood sreum, case T.O ( ) or $10 \%$ adult serum $(0)$. Results are expressed as mean \pm S.D. (3 plates).

Although the physiological behavior of BPA is still obscure, the observation that bursts are always larger in culture with cord blood serum suggests that BPA possesses two kinds of actions; 1) stimulation of recruitment of BFU-E from stem cells, 2) enhancement of cell division during the process of erythroid burst formation. Recently, Terasawa et al. (1980) demonstrated that BPA obtained from both bone marrow conditioned medium and T-lymphoblastic cell line (Mo) conditioned medium enhanced fetal hemoglobin synthesis in BFU-E colonies and suggested that BPA might be an important modulator of fetal hemoglobin synthesis and/or a regulator of F-cell (BOYER et al., 1975) production. Cord blood BPA 
may therefore play a role in active erythropoiesis or in the high level of fetal hemoglobin synthesis found in fetuses. Whether or not these actions are mediated by a single factor cannot be determined from the present study alone. The characterization and purification of BPA may provide further insight into the regulation of the early stages of erythropoiesis.

We thank Ms. Kaoru Sugano, Ms. Setsuko Okoshi, and the obstetrics nurses of Jusendo General Hospital for their excellent assistance.

\section{REFERENCES}

Axelrad, A. A., McLeod, D. L., Shreeve, M. M., and Heath, D. A. (1974) Properties of cells that produce erythropoietic colonies in vitro. In: Hemopoiesis in Culture, ed. by RoBInson, W. U.S. Government Office, Washington, D.C., pp. 226-234.

AYE, M. T. (1977) Erythroid colony formation in cultures of human marrow: Effects of leukocytes conditioned medium. J. Cell Physiol., 91: 69-78.

Boyer, S. H., Belding, T. K., Margolet, L., Burke, P. J., and Bell, W. R. (1975) Variations in the frequency of fetal hemoglobin bearing erythrocytes (F-cells) in well adults, pregnant women, and adult leukemics. Johns Hopkins Med. J., 137, pp. 105-115.

EAves, C. J., Humphries, R. K., and EAves, A. C. (1979) In virto characterization of erythroid precursor cells and the differentiation process. In: Cellular and Molecular Regulation of Hemoglobin Switching, ed. by Stamatoyannopoulos, G. and Nienhuis, A. W. Grune and Stratton, New York, pp. 251-270.

Halvorsen, S. (1963) Plasma erythropoietin levels in cord blood and in blood during the first week of life. Acta Paediatr. Scand., 52: 425-435.

Hara, H. and Ogawa, M. (1978) Erythropoietic precursors in mice under erythropoietic stimulation and suppression. Exp. Hematol., 5: 141-148.

Iscove, N. N. and Guilbert, L. J. (1978) Erythropoietin independent of early erythropoiesis and two regulator models of proliferative control in the hemopoietic system. In: In Vitro Aspects of Erythropoiesis, ed. by Murphy, M. J. Springer-Verlag, New York and Berlin, pp. 3-7.

Iscove, N. N., Sieber, F., and Winterhalter, K. H. (1974) Erythroid colony formation in cultures of mouse and human bone marrow: Analysis of the requirement for erythropoietin by gel filtration and affinity chromatography on agarose-concanavalin A. J. Cell Physiol., 83: 309-320.

Kasai, S., Terasawa, W., Kodama, H., and Terasawa, T. (1980) Enhancement of erythroid colony formation in vitro by spleen extract from irradiated rats. Jph. J. Physiol., 30: 767774.

Kidoguchi, K., Ogawa, M., Karam, J. D., and Martin, A. G. (1978) Augmentation of fetal hemoglobin synthesis in culture by human erythropoietic precursors in the marrow and blood: Studies in sickle cell anemia non-hemoglobinopathic adults. Blood, 52: 1115-1124.

Kigasawa, H. and NishiHIRA, H. (1980) High human burst-promoting activity (BPA) in sera from childhood aplastic anemia in semi-solid agar. Br. J. Haematol., 46: 303-305.

Kurland, J. I., Meyer, P. A., and Moore, M. A. S. (1980) Synthesis and release of erythroid colony- and burst-potentiating activity by purified population of murine peritoneal macrophages. J. Exp. Med., 151 : 839-852.

LaJTHA, L. G., Gilbert, C. W., and Guzman, E. (1971) Kinetics of haemopoietic colony growth. Br. J. Haematol., 20 : 343-348.

Nathan, D. G., Chess, L., Hillman, D. G., Clarke, B., Breard, J., Merler, E., and Housman,

Vol. 34, No. 2, 1984 
D. E. (1978) Human erythroid burst-forming unit: T-cell requirement for proliferation in vitro. J. Exp. Med., 117: 324-339.

NisSeN, C., ISCOVE, N. N., and SPECK, B. (1979) High burst-promoting activity (BPA) in serum of patients with acquired aplastic anemia. In: Experimental Hematology Today, ed. by Baum, S. J. and Ledney, G. D. Springer, New York, pp. 79-87.

Ogawa, M., Grush, O. C., O'Dell, R. F., Hara, H., and McEachern, M. D. (1977) Circulating erythropoietic precursors assessed in culture: Characterization of in normal men and patients with hemoglobinopathies. Blood, 50: 1081-1092.

Porter, P. N. and OGawa, M. (1982) Characterization of human erythroid burst-promoting activity derived from bone marrow conditioned media. Blood, 59: 1207-1212.

TEALE, F. W. (1959) Cleavage of the haem-protein by acid methylethylketone. Biochim. Biophys. Acta, 35: 543-548.

Terasawa, T., Ogawa, M., Porter, P. N., Golde, D. W., and Goldwasser, E. (1980) Effect of burst-promoting activity (BPA) and erythropoietin on hemoglobin biosynthesis in culture. Blood, 56: 1106-1110. 